\title{
Radiographic aspects of dogs exposed to tobacco smoke
}

\author{
Aspectos radiográficos de cães expostos à fumaça do tabaco \\ Aspectos radiográficos de los perros expuestos al humo del tabaco
}

Received: 07/22/2021 | Reviewed: 07/29/2021 | Accept: 08/04/2021 | Published: 08/09/2021

\author{
Alexandre Redson Soares da Silva \\ ORCID: https://orcid.org/0000-0002-3458-9285 \\ Federal University of São Francisco Valley, Brazil \\ E-mail: alexandre.redson@univasf.edu.br \\ Ana Amélia Domingues Gomes \\ ORCID: https://orcid.org/0000-0003-3514-0778 \\ Federal University of São Francisco Valley, Brazil \\ E-mail: anaamelia.gomes@univasf.edu.br \\ Ana Paula Abreu Mendonça \\ ORCID: https://orcid.org/0000-0002-4238-5768 \\ São Paulo State University, Brazil \\ E-mail: apavet@yahoo.com.br \\ Thalita da Silva Marinho e Silva \\ ORCID: https://orcid.org/0000-0001-8612-2209 \\ Federal University of Recôncavo da Bahia, Brazil \\ E-mail: thalitamarinho750@gmail.com \\ Dielson da Silva Vieira \\ ORCID: https://orcid.org/0000-0002-9209-2250 \\ São Paulo State University, Brazil \\ E-mail: dielsonveterinario@gmail.com \\ Pedro Miguel Ocampos Pedroso \\ ORCID: https://orcid.org/0000-0001-9024-9149 \\ University of Brasília, Brazil \\ E-mail: pedrosovet@yahoo.com.br \\ Maria Jaqueline Mamprim \\ ORCID: https://orcid.org/0000-0002-2238-5584 \\ São Paulo State University, Brazil \\ E-mail: jaqueline.mamprim@unesp.br \\ Maerle Oliveira Maia \\ ORCID: https://orcid.org/0000-0003-3770-6990 \\ Federal University of Mato Grosso, Brazil \\ E-mail: maerlemaiamv@gmail.com \\ Thaís Rabelo dos Santos-Doni \\ ORCID: https://orcid.org/0000-0002-8300-0473 \\ Federal University of Jequitinhonha and Mucuri Valleys, Brazil \\ E-mail: rabelo.vet@hotmail.com
}

\begin{abstract}
Knowledge of the deleterious effects of passive smoking in dogs is inconclusive and scarce. The present study investigated pulmonary radiographic aspects of dogs exposed to cigarette smoke daily. Thirty dogs were used (15 from households where smoking was reported and 15 dogs from households where there was no smoking), older than two years, regardless of sex, race, skull composition and clinical signs from september 2014 and june 2015. Chest Xrays were taken in all dogs to characterize possible lung lesions with analysis performed in a double-blind study and a questionnaire was applied to the tutors. The analysis of these data provided that $33.33 \%$ of passive smoking dogs showed clinical signs like those observed in passive smokers, although there was no significant association between the risk factors. Lung injuries were observed in all passive smoking dogs. The link between dogs, their smoking guardians and respiratory diseases is difficult. This study demonstrates pulmonary radiographic alterations suggestive of bronchial pulmonary disease were observed in $100 \%$ of passive smoking dogs. Thus, we can conclude that, regardless of the time of exposure to smoke, living with smokers' guardians is a risk to the health of animals. Our results suggest the harmful action of exposure to cigarette smoke as a risk factor for lung health in dogs.
\end{abstract}

Keywords: Canines; Lung; Radiography; Smoking.

\section{Resumo}

O conhecimento dos efeitos deletérios do fumo passivo em cães é inconclusivo e escasso. O presente estudo investigou aspectos radiográficos pulmonares de cães expostos à fumaça de cigarro diariamente. Foram utilizados 30 cães (15 de domicílios onde fumar foi relatado e 15 cães de domicílios onde não havia fumo), com mais de dois anos, 
independentemente do sexo, raça, composição do crânio e sinais clínicos de setembro de 2014 a junho de 2015. Radiografias de tórax foram analisadas em todos os cães para caracterização de possíveis lesões pulmonares com análise realizada em estudo duplo-cego e questionário aplicado aos tutores. Pela análise dos dados foi possível observar que 33,33\% dos cães fumantes passivos apresentassem sinais clínicos semelhantes aos observados em humanos fumantes passivos, embora não houvesse associação significativa entre os fatores de risco. Lesões pulmonares foram observadas em todos os cães fumantes passivos. A ligação entre os cães, seus tutores fumantes e as doenças respiratórias é difícil. Este estudo demonstra que alterações radiográficas pulmonares sugestivas de doença pulmonar brônquica foram observadas em $100 \%$ dos cães fumantes passivos. Assim, podemos concluir que, independentemente do tempo de exposição à fumaça, morar com os responsáveis pelos fumantes é um risco à saúde dos animais. Nossos resultados sugerem a ação nociva da exposição à fumaça do cigarro como fator de risco para a saúde pulmonar em cães.

Palavras-chave: Caninos; Pulmão; Radiografia; Tabagismo.

\section{Resumen}

El conocimiento de los efectos nocivos del humo de segunda mano en los perros no es concluyente y es escaso. El presente estudio investigó aspectos radiográficos pulmonares de perros expuestos al humo del cigarrillo a diario. Se utilizaron treinta perros (15 de hogares donde se reportó fumar y 15 perros de hogares donde no se fumaba), mayores de dos años, independientemente del sexo, raza, composición del cráneo y signos clínicos desde septiembre de 2014 y junio de 2015. Se tomaron radiografías de tórax en todos los perros para caracterizar posibles lesiones pulmonares con análisis realizado en un estudio doble ciego y un cuestionario aplicado a los guardianes. El análisis de estos datos permitió que el 33,33\% de los perros fumadores pasivos presentaran signos clínicos similares a los observados en los fumadores pasivos, aunque no hubo asociación significativa entre factores de riesgo. Se observaron lesiones pulmonares en todos los perros fumadores pasivos. El vínculo entre los perros, sus guardianes fumadores y las enfermedades respiratorias es difícil. Este estudio demuestra que se observaron cambios radiográficos pulmonares sugestivos de enfermedad pulmonar bronquial en el 100\% de los perros fumadores pasivos. Así, podemos concluir que, independientemente del tiempo de exposición al humo, convivir con los responsables de los fumadores supone un riesgo para la salud de los animales. Nuestros resultados sugieren la acción nociva de la exposición al humo del cigarrillo como factor de riesgo para la salud pulmonar de los perros.

Palabras clave: Caninos; Pulmón; Radiografía; Tabaquismo.

\section{Introduction}

Exposure to environmental tobacco smoke (ETS), such as cigarettes, through secondhand smoke consists of inhaling toxic substances (INCA, 2018) and leads to known diseases in humans (Pichini, Alteiri, Pellegrini, Pacifici, \& Zuccaro, 1997; Wipfli et al 2008). According to the World Health Organization, there is no safe level of exposure to secondhand tobacco smoke, which is responsible for more than 1.2 million premature deaths per year worldwide (WHO, 2019). This smoke dispersed in the environment also affects pets, the association between tobacco smoke and disease has been difficult to prove, according to studies based on (PARK et al. 1977, Reif, Dunn, Ogilvie, \& Harris, 1992, Roza \& Viegas, 2007).

In dogs studies related to ETS show a significant increase in the risk of lung cancer (Reif, Dunn, Ogilvie, \& Harris, 1992), nasal cavity and paranasal sinuses (Reif, Bruns, \& Lower, 1998). The analyzes performed by Hawkins and collaborators (2010), showed that chronic cough is frequent in dogs exposed to ETS, but they were unable to confirm the association. However, the effect of passive exposure to tobacco smoke on lung function with chronic cough was confirmed by Yamaya and collaborators (2014), in which they show increased airway limitation in dogs with chronic cough and suggested that tobacco smoke contributes to the development of increased sputum secretion.

Regarding the diagnosis, the radiographic examination is essential for the investigation of respiratory system affections (Pavelski et al. 2017), however, as far as the authors' knowledge is concerned, there is no study on the radiographic evaluation of passive smoking dogs so far. In view of the scarce information on the effects of cigarette smoke on the respiratory system of dogs, this study aimed to radiographic characterization of lung lesions and to identify risk factors in passive smoking canines. 


\section{Methodology}

The current study is retrospective one, from september 2014 and june 2015, 30 adult dogs were referred to the University Hospital of Veterinary Medicine of the Federal University of Recôncavo da Bahia (HUMV-UFRB), were divided into two groups: passive smokers (Group 1) and non-smokers (Group 2).

Passive smokers lived for at least two years with tutors who smoked an average of 20 cigarettes a day for at least 24 months and consisted of 15 dogs with some type of clinical signs or none. The 15 non-smoking dogs, on the other hand, had no respiratory disease and had no contact with cigarette smoke, constituted the control group. The owners answered some questions about the habit of smoking, during the anamnesis of the animals, as well as information on age, breed, sex, and skull conformation was obtained for each dog.

In order to characterize the type, frequency and distribution of possible pulmonary lesions, the dogs were tested through thoracic radiographic examinations according to the thickness of the chest of each animal (De Martin \& Iwasaki, 1976), with right and left lateral and ventrodorsally positions, analyzed by the software (eFilm Workstation ${ }^{\mathrm{TM}}$ Brazil Version 3.3.5), performed at a right angle to each other, in compliance with the radiological protection standards (Kealy, McAllister, \& Graham, 2012). The radiographic analyzes of the appendicular skeleton were based on a basic process, determining the extension and involvement of adjacent soft tissues (Thrall, 2015). Furthermore, the imaging analyzes were performed in a double-blind study, by radiologists with notable experience.

Data from both groups of exposed and unexposed dogs were tabulated in a Microsoft ${ }^{\circledR}$ Office Excel spreadsheet to perform descriptive statistical analysis. The verification of frequencies was obtained by the total values (fi) and percentages (\%) of the radiographic findings. Similarly, the variables sex, race, age and skull conformation were tested. About radiographic examinations, descriptive analyzes were performed regarding the frequencies, distribution, characterization, and occurrence of lesions. The associations of risk factors were observed by the odds ratios of occurrence (Odds ratio - OR), confidence interval (CI) of $95 \%$ and $\mathrm{p}<0.05$ was considered statistically significant.

\section{Results}

At Table 1 shows the association between race, age, sex and skull conformation with smoker's owners. Thirty dogs were included in the study. The median age was 6 years (ranging from 2 years to 11 years). Thirteen dogs were males and 17 females. There was no racial predisposition, with 40 and $60 \%$ of the sample being composed of mixed-breed dogs. Of the animals that lived with smokers, 33.33\% (5/15) showed clinical changes in the respiratory system: easy tiredness, nasal discharge, coughing and sneezing, there was no statistically significant difference $(p=0.15)$. Radiographic changes were only observed in the passive smoker group. The guardians of passive smoking dogs used industrial-type tobacco, with an average of 16 years of smoking, with daily consumption of 10 to 60 cigarettes per day, being smoked indoors, in addition to having respiratory affections such as pulmonary emphysema, respiratory distress, asthma bronchial and chronic cough. 
Table 1. Association between sex, age and race and passive inhalation of cigarette smoke. Odds ratio (OR) and respective 95\% confidence interval (CI).

\begin{tabular}{|c|c|c|c|c|c|c|c|}
\hline \multirow{3}{*}{ Risk factors } & \multicolumn{6}{|c|}{ Study groups $(n=30)$} & \multirow{3}{*}{ P value ${ }^{(1)}$} \\
\hline & \multicolumn{2}{|c|}{ Passive Smokers } & \multicolumn{2}{|c|}{ Nonsmokers } & \multirow{2}{*}{ OR } & \multirow{2}{*}{ CI $95 \%$} & \\
\hline & $\mathbf{n}$ & $\%$ & $\mathbf{n}$ & $\%$ & & & \\
\hline \multicolumn{8}{|l|}{ Sex } \\
\hline Female & $8 / 15$ & 53.33 & $9 / 15$ & 50.00 & 1,5 & \multirow{2}{*}{$0.31-7.18$} & \multirow{2}{*}{0.61} \\
\hline Male & $7 / 15$ & 46.67 & $6 / 15$ & 60.00 & 1 & & \\
\hline \multicolumn{8}{|l|}{ Years } \\
\hline$>7$ years & $4 / 15$ & 26.66 & $4 / 15$ & 26.66 & 1 & $0.23-6.31$ & 1.00 \\
\hline \multicolumn{8}{|l|}{ Breed } \\
\hline Defined race & $7 / 13$ & 53.85 & $6 / 15$ & 46.15 & 1.75 & \multirow{2}{*}{$0.38-7.85$} & \multirow{2}{*}{0.46} \\
\hline Not defined race & $6 / 13$ & 40.00 & $9 / 15$ & 60.00 & 1 & & \\
\hline \multicolumn{8}{|l|}{ Skull conformation } \\
\hline brachycephalic & $2 / 13$ & 33.33 & $4 / 15$ & 66.67 & 0.50 & $0.075-3.31$ & 0.47 \\
\hline
\end{tabular}

${ }^{(1)}$ Chi-square test or Fisher's exact test $(\mathrm{p}<0.05)$. Source: Authors.

Radiographic changes (Table 2) were only observed in the passive smoker group, thus pulmonary changes were detected in all dogs belonging to the group, that is, increased generalized pulmonary opacity, with a bronchial pattern with signs of mineralization in 66.66\% (10/15), increase in generalized pulmonary opacity, of mixed pattern (bronchial and vascular) in 53.33\% (8/15) and increase in localized pulmonary opacity, also of bronchial pattern in $26.67 \%$ (4/15), in addition, $26.67 \%$ (4/15) dogs had generalized cardiomegaly and 53.33\% (8/15) showed pulmonary congestion (Figure1). The radiographic changes showed no significant statistically with age or duration of exposure to smoke of cigarettes, since the tutors have been with the dogs since they were puppies (OR: 3.75; CI: $0.27-51.37 ; \mathrm{p}=0.55$ ).

Table 2. Radiographic changes observed in the passive smoker group.

\begin{tabular}{lcc}
\hline & Radiographic changes & N/Total \\
\hline Increased generalized pulmonary opacity, with a bronchial pattern with signs of mineralization & $10 / 15$ & $66.66 \%$ \\
Increase in generalized pulmonary opacity, of mixed pattern (bronchial and vascular) & $5 / 15$ & $4 / 15$ \\
Increase in localized pulmonary opacity, also of bronchial pattern & $26.67 \%$ & $26.67 \%$ \\
Generalized cardiomegaly & 53.15 \\
Pulmonary congestion & $8 / 15$ \\
\hline
\end{tabular}

Source: Authors. 
Figure 1. Thoracic digital radiographic images of dogs naturally exposed to cigarette smoke showing increased generalized lung opacity with a bronchial pattern: (A) Right laterolateral projection; (B) Ventrodorsal projection. Radiographic image of an mixed-breed dog, male, 3 years old, passive smoker: (C) Right lateral projection, presence of tortuous venous congestion (arrow) and bronchial pattern with mineralization; (D) Left projection, presence of venous congestion, tortuous (arrows) and bronchial pattern with mineralization.
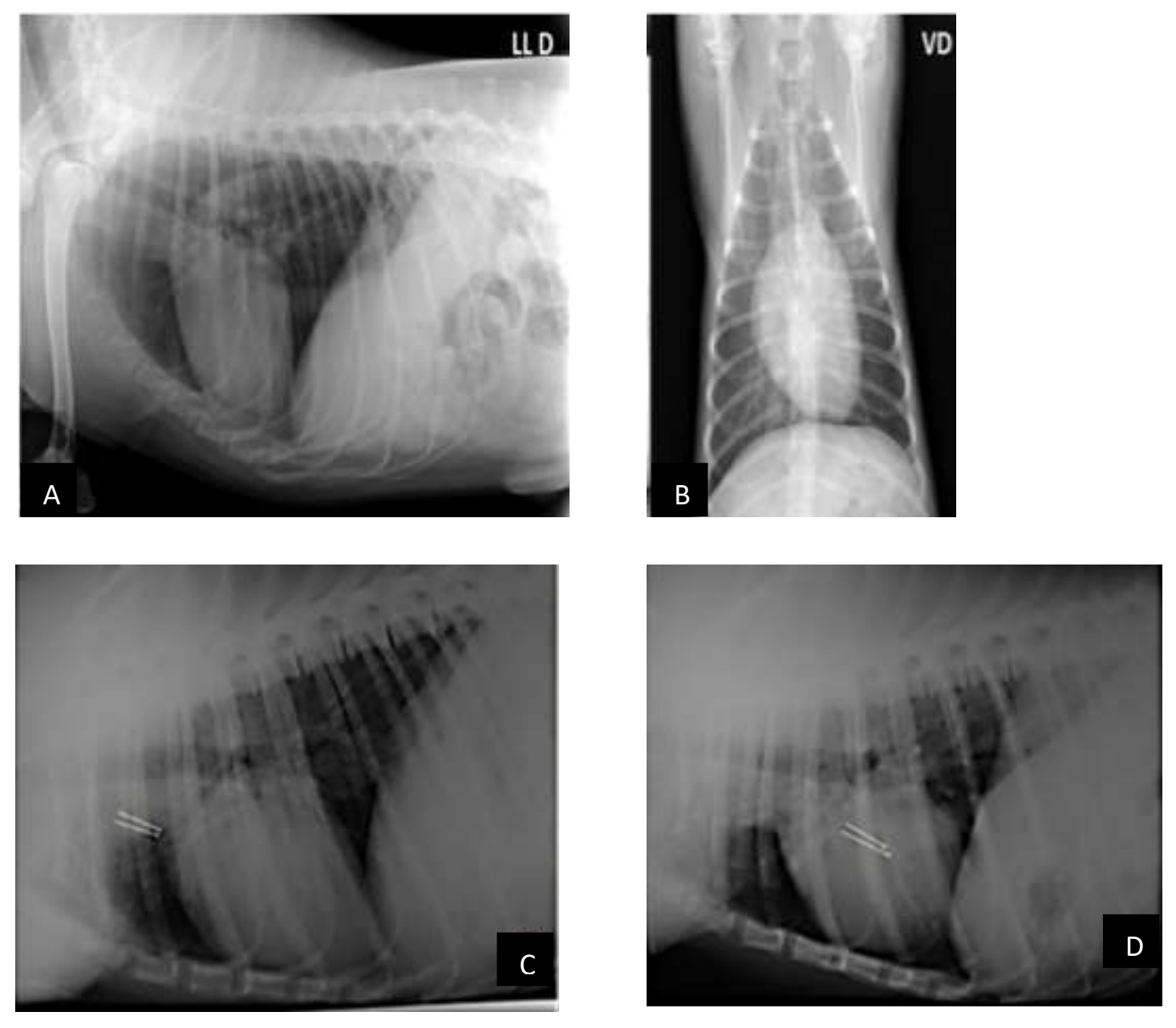

Source: Authors.

\section{Discussion}

In our study, we investigated the pulmonary radiographic aspects of passive smoking dogs. In human medicine, smoking has a harmful effect on many organ systems and is responsible for ischemic heart disease, lower respiratory infections, asthma and lung cancer (Öberg, Jaakkola, Woodward, Peruga, \& Prüss-Ustün, 2011; Thandra, Barsouk, Saginala, Aluru, \& Barsouk, 2021), therefore, passive smoking is a danger to the health of non-smoking humans (Jayes et al., 2016; Abebe, Gebru, Amenu, Mekonnen, \& Dube, 2021).

Tobacco products, both smokeless and combustible, play a large role in the development of neoplasm in addition to leading to poorer treatment outcomes. Still, tobacco is used throughout the world and, in some pockets, at very high rates (Jethwa \& Khariwala, 2017). Balansky et al. (2018) confirm histopathological changes were induced by exposure the cigarette smoke. Therefore, an exposure period of 1 month seems to be sufficient to induce most inflammatory, degenerative and preneoplastic lesions, both in the lung and in the urinary tract. However, it takes 2 to 4 months of exposure to induce neoplastic 
lesions in the lung. In addition to increased susceptibility at birth, continuous exposure to mainstream cigarette smoke in mice during the first 4 months of life, involving a higher cumulative exposure dose, may have contributed to increased tumor development, according to hypotheses raised in humans. In fact, certain lung diseases in adults can have their roots in the early stages of life, and early onset of smoking confers an increased risk of lung cancer to the point of up to $52.4 \%$ of cases of lung cancer in men and up to $73.0 \%$ of lung cancer cases in women can be attributed to the effect of smoking for the first time at an early age.

In this research passive smoking dogs showed clinical signs of coughing, dyspnea, easy tiredness and fatigue, which are related to respiratory diseases. There is long-standing evidence that lung disease is related to exposure to cigarette smoke in animals (Auerbach, Hammond, Apanha, \& Garfinkel, 1967; Roza \& Viegas, 2007; Yamaya, Sugiya, \& Watari, 2014).

In veterinary medicine there are no studies that correlate the sex and age of dogs with passive tobacco inhalation, here there were no significant differences between the groups between breed, age, sex and skull conformation of the studied animals and contact with smoking tutors. However, Reif and collaborators (1992) and Reif and collaborators (1998), associated a higher frequency of nasal neoplasms in dolicephalic dogs, while brachycephalic and midcephalic animals were more prone to the formation of lung neoplasms. Hawkins and collaborators (2010) observed that toy breed dogs have a greater association for tracheobronchomalacia. Yamaya and collaborators (2014), observed persistent increases in airway limitation in dogs with chronic cough exposed to tobacco.

Chronic bronchitis is a complex disease of the lower respiratory tract that can present important radiographic changes. In this study, the bronchial pattern with signs of mineralization in passive smoking dogs was seen in animals aged less or more than seven years old (80.00\%) and radiographic changes were not consistent with age or time of exposure to cigarette smoke with $\mathrm{p}=0.55$, as it is common to observe mineralized bronchi in older animals (Kealy \& Mcallister, 2005; Berry, Graham, \& Thrall, 2010). Increased bronchial pattern opacity is the most frequent radiographic lung lesion found in this study in passive smoking dogs. Hori and collaborators (2016) in a meta-analysis review concluded that secondhand smoke significantly increases the risk of lung cancer, not only active smoking as a large portion of the population believes.

In addition, cigarette smoke and smoking is an important risk factor for the development of cardiovascular disease (Kondo, Nakano, Adachi, \& Murohara, 2019). The pulmonary congestion observed in 53.33\% of animals belonging to the passive smoker group can be the result of any condition that causes an increase in cardiac output from left to right, or in cases of early stages of inflammatory processes such as those caused by cigarette smoke, despite not being displayed in the last condition (Kealy \& Mcallister 2005). These findings may be suggestive of interstitial fibrosis and similar to those observed in human smokers, however, pathological evaluation is necessary for confirmation (Galvin, Frazier, \& Franks, 2010).

There was no association between the breed, age and sex of the animals and living with smoker's owners. Although only $40 \%$ of animals exposed to smoke presented clinical signs similar to those found in humans, pulmonary radiographic alterations suggestive of pulmonary disease were observed in $100 \%$ of passive smoking dogs. Thus, we can conclude that, regardless of the time of exposure to smoke, living with smokers' guardians is a risk to the health of animals.

\section{Conclusion}

This study demonstrates pulmonary radiographic alterations suggestive of bronchial pulmonary disease were observed in $100 \%$ of passive smoking dogs. Thus, we can conclude that, regardless of the time of exposure to smoke, living with smokers' guardians is a risk to the health of animals. Our results suggest the harmful action of exposure to cigarette smoke as a risk factor for lung health in dogs. 


\section{Acknowledgments}

To FAPESB/PIBIC programs (Proc. $n^{\circ}$ FAPESB 5529/2014) and UFRB/PIBIC for granting the Scientific Initiation scholarship. To HUMV-UFRB for providing the facilities and equipment to carry out clinical and radiographic examinations, to technician Helenildo Santana dos Santos (UFRB, Cruz das Almas, BA) for his valuable help.

\section{References}

Abebe, S., Gebru, G., Amenu, D., Mekonnen, Z., \& Dube, L. (2021). Risk factors associated with congenital anomalies among newborns in southwestern Ethiopia: A case-control study. PLoS One, 16(1), e0245915. doi:10.1371/journal.pone.0245915

Auerbach O., Hammond, C. E, Apanha, D., \& Garfinkel, E. U. (1967). Enfisema produzido em cães pelo tabagismo. Jama,199(4), $241-246$.

Balansky R, Ganchev G, Iltcheva M, Dimitrova E, Micale RT, La Maestra S, De Flora S. Carcinogenic response and other histopathological alterations in mice exposed to cigarette smoke for varying time periods after birth. Carcinogenesis. 2018 Apr 5;39(4):580-587. 10.1093/carcin/bgy013.

Berry, C. R., Graham, J. P. \& Thrall, D. E. (2010). Diagnóstico de radiologia veterinária. In: D. E. Thrall. Diagnóstico de radiologia veterinária, (5a ed.), Rio de Janeiro: Elsevier, 462-485.

De Martin, B. W., \& Iwasaki, M. (1976). Noções de radiodiagnóstico veterinário. 50.

Galvin, J. R., Frazier, A. A., \& Franks, T. J. (2010). Collaborative radiologic and histopathologic assessment of fibrotic lung disease. Radiology, 255(3), 25563.

Hawkins, E. C., Clay, L. D., Bradley, J. M., \& Davidian, M. (2010). Demographic and historical findings, including exposure to environmental tobacco smoke, in dogs with chronic cough. Journal of Veterinary Internal Medicine, 24, 825-831.

Hori, M., Tanaka, H., Wakai, K., Sasazuki, S., \& Katanoda, K. (2016). Secondhand smoke exposure and risk of lung cancer in Japan: a systematic review and meta-analysis of epidemiologic studies. Japanese Journal of Clinical Oncology, 46(10), 942-951.

INCA. Instituto Nacional do Câncer. Ministério da Saúde. Tabagismo passivo (2018). .

Jayes, L., Haslam, PL, Gratziou, CG, Powell, P., Britton, J., Vardavas, C., \& De Grada Orive, J. I. (2016). SmokeHaz: Systematic reviews and meta-analyses of the effects of smoking on respiratory health. Chest Journal, 150(1), 164-179.

Jethwa AR, Khariwala SS. Tobacco-related carcinogenesis in head and neck cancer. Cancer Metastasis Rev. 2017 36(3):411-423. 10.1007/s10555-017-96896. PMID: 28801840; PMCID: PMC5709040.

Kealy, J. \& McAllister, H. (2005). Radiologia e ultrassonografia do cão e gato, (3a ed.), Manole, 373.

Kealy, J. K., McAllister, H., \& Graham, J. P. (2012). Respiratory System. In: Diagnostic radiology and ultrassonography of the dog and cat, (5a ed.), Elsevier, St. Louis, 600 .

Kondo, T., Nakano, Y., Adachi, S., \& Murohara, T. (2019). Effects of tobacco smoking on cardiovascular disease. Circulation Journal, 83, 1980-1985.

Öberg, M., Jaakkola, M. S., Woodward, A., Peruga, A., \& Prüss-Ustün. (2011). Worldwide burden of disease from exposure to second-hand smoke: a retrospective analysis of data from 192 countries. The Lancet, 377, 139-146.

Park, S. S., Kikkawa, Y., Goldring, I. P., Daly, M. M., Zelefsky M., Shim C., \& Morita, T. (1977). An animal model of cigarette smoking in beagle dogs: Correlative evaluation of effects on pulmonary function, defense and morphology. The American Review of Respiratory Disease, 115(6), 971-979.

Pavelski1, M., Amaral, D. V. K., Vieira, G. P., Warth, J. F. G., Dittrich, R. L., Dornbusch, P. T., \& Froes, T. R. (2017). Comparative analyses of thoracic radiographs and bronchoalveolar lavage of dogs and cats with chronic bronchial diseases. Semina: Ciências Agrárias, 38(3), $1403-1416$.

Pichini, S., Alteiri, I., Pellegrini, M., Pacifici, R., \& Zuccaro, P. (1997). The analysis of nicotine in infants hair for measuring exposure to environmental tobacco smoke. Forensic Science International, 84, 253-258.

Reif, J. S., Bruns, C., \& Lower, K. S. (1998). Cancer of the nasal cavity and paranasal sinuses and exposure to environmental tobacco smoke in pet dogs. American Journal of Epidemiology, 147(5), 488-492.

Reif, J. S., Dunn, K., Ogilvie, G. K., \& Harris, C. K. (1992). Passive smoking and canine lung cancer risk. American Journal of Epidemiology, 135(3), 234239.

Roza, M. R., \& Viegas, C. A. A. (2007). The dog as a passive smoker: effects of exposure to environmental cigarette smoke on domestic dogs. Nicotine \& Tobacco Research, 9(11), 1171-1176.

Thandra, K. C., Barsouk, A., Saginala, K., Aluru, J. S., \& Barsouk, A. (2021). Epidemiology of lung cancer. Contemporary oncology (Poznan, Poland), 25(1), 45-52. https://doi.org/10.5114/wo.2021.103829

Thrall, D. E. (2015). Princípios de Interpretação Radiográfica do Tórax. In: Diagnóstico de radiologia veterinária, (5a ed.), Elsevier, $474-487$.

WHO. World Health Organization. Tobacco (2019). https://www.who.int/en/news-room/fact-sheets/detail/tobacco. 
Research, Society and Development, v. 10, n. 10, e224101018559, 2021

(CC BY 4.0) | ISSN 2525-3409 | DOI: http://dx.doi.org/10.33448/rsd-v10i10.18559

Wipfli, H., Avila-Tang, E., Navas-Acien, A., Kim, S., Onicescu, G., Yuan, J., \& Samet, J. M. (2008) Secondhand smoke exposure among women and children: evidence from 31 countries. American Journal of Public Health, 98, 672-679

Yamaya, Y., Sugiya, H., \& Watari, T. (2014). Tobacco exposure increased airway limitation in dogs with chronic cough. Veterinary Record, e174-18. 